\title{
PENGARUH LEVERAGE DAN FAKTOR LAINNYA TERHADAP MANAJEMEN LABA PADA PERUSAHAAN NON KEUANGAN
}

\author{
STEFANI MAGDALENA CHANDRA \\ INDRA ARIFIN DJASHAN \\ STIE Trisakti \\ indra@stietrisakti.ac.id
}

\begin{abstract}
The aim of this research is to provide empirical evidence about the effect of profitability, leverage, firm size, audit quality, firm age, board of commissioner, board of directors, audit comittee, and managerial ownership on earnings management. Population of this research are non-financial companies listed in Indonesia Stock Exchange from 2012-2016. The samples of this study are 310 data using purposive sampling method. This research uses multiple regression method for data analysis. The result of this research shows that board of commissioner have effect on earnings management but, leverage, firm size, audit quality, firm age, board of directors, audit comittee, and managerial ownership do not have effect on earnings management.
\end{abstract}

Keywords: Earnings Management, Board of Commissioner, Profitability, Leverage, Audit Quality, and Firm Size.

\begin{abstract}
Abstrak: Tujuan penelitian ini adalah untuk menyediakan bukti empiris mengenai pengaruh profitabilitas, leverage, ukuran perusahaan, kualitas audit, umur perusahaan, dewan komisaris, dewan direksi, komite audit, dan kepemilikan managerial terhadap manajemen laba. Populasi penelitian ini adalah perusahaan non-keuangan yang terdaftar pada Bursa Efek Indonesia selama tahun 2012-2016. Sampel penelitian ini berjumlah 310 sampel dengan menggunakan metode purposive sampling. Penelitian ini menggunakan metode regresi berganda untuk menganalisis data. Hasil penelitian ini menunjukkan dewan komisaris memiliki pengaruh terhadap manajemen laba, sedangkan profitabilitas, leverage, ukuran perusahaan, kualitas audit, umur perusahaan, dewan direksi, komite audit, dan kepemilikan managerial tidak memiliki pengaruh terhadap manajemen laba.
\end{abstract}

Kata Kunci: Manajemen Laba, Dewan Komisaris, Profitabilitas, Leverage, Kualitas Audit, Ukuran Perusahaan. 


\section{PENDAHULUAN}

Banyak perusahaan yang melakukan kegiatan memanipulasi laporan keuangan mereka dengan alasan yang berbeda. Laporan keuangan adalah alat yang sangat berguna bagi suatu perusahaan, misalnya dapat digunakan untuk menarik investor dan dalam mengajukan peminjaman melalui bank. Perusahaan berupaya untuk menghasilkan laporan keuangan yang terlihat fair. Indonesia masih dalam posisi sebagai negara berkembang yang masih membutuhkan modal investasi untuk melakukan perluasan bisnis. Untuk menarik para investor, perusahaan di Indonesia haruslah mempunyai laporan keuangan yang fair di mata investor.

Di Indonesia terdapat kasus manajemen laba, salah satunya yaitu kasus PT. Inovisi Infracom Tbk (INVS) pada periode September 2014 yang dinyatakan memiliki laporan keuangan salah saji. Dalam keterbukaan informasi INVS pada Februari 2015, terdapat delapan item dalam laporan keuangan PT Inovisi yang harus diperbaiki untuk kedua kalinya. Bursa Efek Indonesia (BEI) meminta PT Inovisi untuk merevisi nilai asset tetap, laba bersih per saham, laporan segmen usaha, kategori instrumen keuangan, dan jumlah kewajiban dalam informasi segmen usaha.

Manajemen laba telah menjadi perhatian besar dan konsisten di antara praktisi dan regulator dan telah menerima banyak perhatian dalam literatur akuntansi. Beberapa teknik dan alasan ada untuk praktik setiap manajemen laba didasarkan pada tujuan manajemen (Bassiouny, 2016). Penelitian ini menekankan laporan keuangan yang merupakan pusat sumber informasi bagaimana perusahaan dalam melakukan seluruh kegiatannya baik operasional maupun kegiatan diluar operasional dapat dimanipulasi.

\section{Teori Keagenan}

Teori ini mempunyai asumsi bahwa antara pihak prinsipal dan manajemen, masingmasing memiliki kepentingannya sendiri, sehingga dapat menimbulkan konflik kepentingan antara pihak prinsipal dan manajemen. Biasanya konflik dalam perusahaan timbul karena terdapat kelebihan aliran kas, dimana menyebabkan perbedaan kepentingan karena pemegang saham menyukai investasi yang memiliki tingkat pengembalian yang tinggi dimana tingkat risikonya juga tinggi, dan sebaliknya agen menginginkan investasi yang memiliki tingkat risiko yang rendah dan tingkat pengembaliannya juga akan mengikuti risikonya.

\section{Teori Signal}

Pemberian signal mengenai kondisi perusahaan kepada masyarakat dilakukan oleh manajer tingkat atas (Scott, 2015). Salah satu alat yang digunakan oleh perusahaan untuk menarik calon investor adalah laporan keuangan. Sehingga perusahaan tentunya ingin menyajikan laporan keuangan yang baik di mata investor jika ingin mendapatkan dana dari investor. Salah satunya cara yaitu dengan memanipulasi laporan keuangan tersebut. Teori ini menunjukkan kecenderungan dalam adanya ketidakseimbangan informasi di antara prinsipal dan manajemen.

\section{Teori Efisiensi Pasar}

Kecepatan suatu pasar bereaksi terhadap suatu informasi di mana berguna untuk mencapai harga keseimbangan adalah hal yang penting. Terdapat adanya penyesuaian harga sekuritas menuju harga keseimbangan sebagai respon untuk informasi yang masuk ke pasar. Teori efisiensi pasar ini sudah dipelajari dalam waktu yang lama. Maka, penelitian di dalam bidang efisiensi pasar ini sangat penting bagi investor baik private atau institusional. Teori efisiensi pasar juga terkait dengan model keuangan lainnya. Dipercaya bahwa rasionalitas 
milik pemain di pasar diperlukan (Degutis dan Novickyte 2014)

\section{Profitabilitas dan Manajemen Laba}

Profitabilitas adalah salah satu perhitungan rasio utama dalam menilai suatu perusahaan. Rasio ini digunakan untuk mengukur keefektifan kegiatan operasional perusahaan dalam menghasilkan laba. Dalam penelitian ini rasio yang diambil dalam menghitung profitabilitas adalah return on asset (ROA). Return on Asset adalah suatu rasio untuk mengukur kemampuan perusahaan dalam menghasilkan laba dari aset yang dimilikinya. Hipotesis yang diajukan adalah:

$\mathrm{H}_{1} \quad$ : Profitabilitas memberikan pengaruh terhadap manajemen laba

\section{Leverage dan Manajemen Laba}

Leverage menggambarkan seberapa banyak operasi perusahaan dibiayai dengan hutang (Amertha et al. 2014). Leverage dalam penelitian ini menggunakan rasio debt to total asset ratio (DAR). Debt to total asset merupakan salah satu rasio yang digunakan dalam mengukur tingkat solvabilitas perusahaan. Debt to total asset digunakan untuk menghitung nilai aset perusahaan yang dibiayai dengan hutang. Hipotesis yang diajukan adalah:

$\mathrm{H}_{2}$ : Leverage memberikan pengaruh terhadap manajemen laba

\section{Ukuran Perusahaan dan Manajemen Laba}

Ukuran Perusahaan adalah cara menilai ukuran sebuah perusahaan. Dalam penelitian ukuran perusahaan adalah cerminan dari kecilnya ukuran perusahaan yang muncul di total aset perusahaan. Ukuran perusahaan dapat dilihat dari ukuran besar kecilnya suatu perusahaan dan dibedakan menjadi perusahaan besar dan perusahaan kecil (Supriatna, 2014). Umumnya, perusahaan yang sudah besar cenderung akan menjaga kestabilan kinerja dan kondisi perusahaan. Hipotesis yang diajukan adalah:
$\mathrm{H}_{3}$ : Ukuran perusahaan memberikan pengaruh terhadap manajemen laba

\section{Kualitas Audit dan Manajemen Laba}

Kualitas audit seorang auditor dapat dilihat dari hasil kerja auditor dan keputusan yang diambil. Umumnya terdapat pemikiran bahwa audit yang berkualitas adalah yang dilaksanakan oleh auditor yang kompeten dan independen. Kompeten artinya menguasai teknologi, memahami, dan melaksanakan prosedur audit dan teknik penyempelan yang benar. Sementara independen artinya bila menemukan pelanggaran maka akan melaporkan pelanggaran tersebut. Hipotesis yang diajukan adalah:

$\mathrm{H}_{4} \quad$ : Kualitas audit memberikan pengaruh terhadap manajemen laba

\section{Umur Perusahaan dan Manajemen Laba}

Umur perusahaan adalah salah satu faktor yang dapat berpengaruh terhadap kinerja perusahaan, serta juga dapat menunjukkan kemampuan perusahaan dalam keunggulan berkompetisi. Perusahaan yang telah lama berdiri lebih dipercaya oleh para investor karena diasumsikan dapat menghasilkan laba yang lebih tinggi (Zen dan Herman 2007). Hipotesis yang diajukan adalah:

$\mathrm{H}_{5}$ : Umur perusahaan memberikan pengaruh terhadap manajemen laba

\section{Dewan Komisaris dan Manajemen Laba}

Dewan Komisaris memiliki tugas untuk melakukan pengawasan dan memberikan nasihat kepada direktur Perseroan Terbatas (PT). Walaupun dewan komisaris memiliki posisi yang lebih kuat dibanding dewan direksi, namun memiliki akses yang lebih sedikit terkait situasi perusahaan (Nugroho dan Eko, 2011). Hipotesis yang diajukan adalah:

$\mathrm{H}_{6} \quad$ : Komisaris independen memberikan pengaruh terhadap manajemen laba 


\section{Dewan Direksi dan Manajemen Laba}

Direksi adalah organ perusahaan yang bertanggung jawab dalam mengelola perusahaan yang mencakup lima tugas utama, yaitu kepengurusan, manajemen resiko, pengendalian internal, komunikasi, dan tanggung jawab sosial (KNKG 2006). Tugas dari Direksi adalah untuk memimpin dan menjalankan perusahaan untuk mencapai tujuan yang diinginkan. Istilah Dewan Direksi sendiri tidak dikenal dalam peraturan perundang-undangan dan anggaran dasar, namun istilah yang dikenal adalah Direksi. Hipotesis yang diajukan adalah:

$\mathrm{H}_{7} \quad$ : Dewan direksi memberikan pengaruh terhadap manajemen laba

\section{Komite Audit dan Manajemen Laba}

Komite audit adalah pihak yang menyediakan saluran komunikasi formal antara dewan, sistem pengawasan internal, dan auditor eksternal (Siam et al 2015). Komite audit diharapkan agar dapat menurunkan tindakan kecurangan yang dilakukan oleh manajer dengan mengawasi tindakan manajer dan memberikan pendapat mengenai hal yang dapat memengaruhi keputusan yang disampaikan oleh Direksi (Lidiawati dan Asyik 2016). Hipotesis yang diajukan adalah:

$\mathrm{H}_{8} \quad$ : Komite audit memberikan pengaruh terhadap manajemen laba

\section{Kepemilikan Manajerial dan Manajemen Laba}

Konflik antara pihak manajemen dengan prinsipal dapat diminimumkan dengan pengawasan dan mensejajarkan kepentingan yang terkait di mana tindakan tersebut tentunya karna memunculkan biaya agensi. Bila terdapat kepemilikan managerial, manager akan cenderung menjalankan perusahaan selaras dengan para pemegang saham (Kristiani 2014). Hipotesis yang diajukan adalah:

$\mathrm{H}_{9} \quad$ : Kepemilikan manajerial memberikan pengaruh terhadap manajemen laba

\section{METODE PENELITIAN}

Populasi yang digunakan dalam penelitian ini adalah perusahaan non-keuangan yang secara konsisten terdaftar dalam Bursa Efek Indonesia (BEI) dengan periode penelitian selama 4 tahun, yaitu pada tahun 2013-2016 sebanyak 386 perusahaan. Hasil dari proses sampel dengan menggunakan teknik purposive sampling menghasilkan sebanyak 78 perusahaan. Sampel yang digunakan dalam penelitian setelah dikurangi data outlier maka jumlah data yang digunakan menjadi sebanyak 310 data (lihat tabel 1).

Manajemen laba dalam penelitian ini diproksikan dengan dicretionary accruals menggunakan modified cross sectional dari model Jones 1995. Menurut Bassiouny (2016) untuk menghitung dicretionary accruals dilakukan dengan langkah-langkah sebagai berikut:

(1) $\mathrm{TA}_{\mathrm{t}}=\mathrm{NI}_{\mathrm{t}}-\mathrm{CFO} \mathrm{t}$

(2) $\frac{T A C_{t}}{A_{t-1}}=\beta_{1 j}\left(\frac{1}{A_{t-1}}\right)+\beta_{2 j}\left(\frac{\Delta R E V_{t}-\Delta A R_{t}}{A_{t-1}}\right)+\beta_{3 j}$ $\left(\frac{P P E_{t}}{A_{t-1}}\right)+\varepsilon_{i t}$

(3) $N D A_{t}=\beta_{1 j}\left(\frac{1}{A_{t-1}}\right)+\beta_{2 j}\left(\frac{\Delta R E V_{t}-\Delta A R_{t}}{A_{t-1}}\right)+\beta_{3 j}$ $\left(\frac{P P E_{t}}{A_{t-1}}\right)$

(4) $D A_{j t}=\frac{T A C_{t}}{A_{t-1}}-N D A_{j t}$

$\mathrm{TA}_{\mathrm{t}}$ total accruals pada tahun $\mathrm{t} ; \mathrm{NI}_{\mathrm{t}}$ laba bersih pada tahun $\mathrm{t}$; $\mathrm{CFO}_{\mathrm{t}}$ arus kas dari kegiatan operasi pada tahun t; TAC total Accrual pada periode t; $\triangle R E V_{t}$ perubahan dalam pendapatan perusahaan j pada tahun t dikurangi $\mathrm{t}-1 ; \Delta \mathrm{AR}_{\mathrm{t}}$ perubahan dalam piutang dagang perusahaan $j$ pada tahun t dikurangi t-1; $\mathrm{PPE}_{\mathrm{t}}$ property, plant, dan Equipment kotor dari perusahaan j pada tahun t; $\mathrm{NDA}_{\mathrm{t}}$ non-dicretionary accruals perusahaan j pada tahun $\mathrm{t}$; $\mathrm{A}_{\mathrm{t}-1}$ total assets perusahaan j pada tahun sebelumnya; $D A_{j t}$ dicretionary accruals perusahaan $\mathrm{j}$ pada tahun $\mathrm{t}$; $\beta_{1 j}, \quad \beta_{2 j}, \quad \beta_{3 j} \quad$ parameter-parameter spesifik perusahaan; $\varepsilon_{\text {it }}$ error 
Profitabilitas adalah sebuah rasio yang digunakan untuk menilai suatu perusahaan. Rasio ini dapat memberitahu seberapa efektifnya suatu perusahaan dalam mendapatkan pengembalian dalam menjalankan kegiatan operasionalnya dengan menggunakan asetnya (Susanto 2013). Pengukuran profitabilitas adalah sebagai berikut (Susanto, 2013):

$$
\mathrm{ROA}=\frac{\text { Net Income }}{\text { Total Assets }}
$$

Leverage menunjukkan juga bagaimana perusahaan mendapatkan kepercayaan dari para investor sebagai pelaku pasar modal. Pengukuran leverage adalah sebagai berikut (Bassiouny, 2016):

$$
\text { LEV }=\frac{\text { Total Debt }}{\text { Total Assets }}
$$

Ukuran Perusahaan biasanya dapat menentukan jumlah return yang diharapkan. Pengukuran ukuran perusahaan adalah sebagai berikut (Bassiouny 2016):

\section{SIZE = Ln (Total Asset)}

Dalam penelitian ini, kualitas audit diukur menggunakan variabel dummy dibedakan menjadi dua kategori, yaitu perusahaan yang diaudit oleh kantor akuntan publik (KAP) Big Four maka diberikan nilai 1 dan perusahaan yang diaudit oleh KAP non-Big Four maka diberikan nilai 0 (Bassiouny, 2016).

Umur perusahaan dalam penelitian ini, umur perusahaan diukur dari berapa lama perusahaan tersebut berdiri. Pengukuran umur perusahaan adalah sebagai berikut (Bassiouny, 2016):

AGE = Jumlah tahun sejak perusahaan berdiri sampai dengan periode penelitian

Dewan Komisaris ditunjuk oleh rapat umum para pemegang saham (RUPS). Pengukuran Dewan Komisaris adalah sebagai berikut (Jatiningrum et al. 2015):

$\mathrm{COM}=$ Jumlah anggota dewan komisaris
Dewan direksi adalah organ perusahaan yang bertanggung jawab dalam mengelola perusahaan (KNKG 2006). Pengukuran dewan direksi adalah sebagai berikut (Jatiningrum et al. 2015):

DIR = Jumlah anggota dewan direksi Komite audit adalah suatu badan yang berada dibawah Komisaris yang sekurangkurangnya minimal satu anggota Komisaris, dan dua anggota ahli yang bukan merupakan pegawai maupun pelaporannya dan bertanggungjawab langsung kepada Komisaris atau Dewan Pengawas (KepMen BUMN No. Kep-103/MBU/2002). Pengukuran komite audit adalah sebagai berikut (Susanto 2013):

COA = Jumlah anggota komite audit yang terdapat dalam suatu perusahaan

Kepemilikan manajerial dapat digunakan untuk mengendalikan pihak manajemen dengan adanya dorongan peningkatan pengawasan sehingga dapat mengurangi kemungkinan terjadinya manajemen laba. Investor managerial adalah investor jangka panjang yang menginginkan perkembangan perusahaan dalam menghasilkan barang atau jasa yang berguna (Monks 2011). Pengukuran kepemilikan institusional adalah sebagai berikut (Aygun et al. 2014):

$$
\text { MAN }=\frac{\text { Jumlah saham yang dimiliki manajerial }}{\text { Total saham beredar }}
$$

\section{HASIL PENELITIAN}

Obyek penelitian yang digunakan dalam penelitian ini adalah perusahaan nonkeuangan yang terdaftar di Bursa Efek Indonesia secara konsisten selama tahun 2012 sampai 2016. Sampel penelitian yang dipakai adalah sebanyak 78 perusahaan yang didapat dengan kriteria sebagai berikut: 
Tabel 1 Hasil Proses Sampel

\begin{tabular}{lcc}
\hline \multicolumn{1}{c}{ Kriteria Sampel } & Perusahaan & Jumlah Data \\
\hline $\begin{array}{l}\text { Perusahaan non-keuangan yang terdaftar di BEI } \\
\text { secara konsisten daru tahun 2012-2016. }\end{array}$ & 386 & 1.544 \\
$\begin{array}{l}\text { Perusahaan tidak menerbitkan laporan keuangan } \\
\text { tahunan yang berakhir pada tanggal 31 Desember. }\end{array}$ & $(21)$ & $(84)$ \\
Perusahaan tidak menerbitkan laporan keuangan & $(72)$ & $(288)$ \\
tahunan dalam mata uang rupiah. & & \\
Perusahaan yang menghasilkan laba negatif. & $(124)$ & $(496)$ \\
Perusahaan tidak memiliki kepemilikan managerial. & $(91)$ & $(364)$ \\
Total perusahaan yang menjadi sampel & 78 & 312 \\
Data outlier & & $(2)$ \\
\hline Jumlah data penelitian & & 310 \\
\hline
\end{tabular}

Hasil uji deskriptif yang dilakukan dapat dilihat dalam tabel sebagai berikut:

Tabel 2 Statistik Deskriptif

\begin{tabular}{|c|c|c|c|c|c|}
\hline Variabel & $\mathrm{N}$ & Minimum & Maximum & Mean & Std.Deviation \\
\hline EAR & 310 & -0.258500 & 0.239830 & -0.00286610 & 0.076979314 \\
\hline ROA & 310 & 0.000242 & 0.401838 & 0.07678770 & 0.069238678 \\
\hline LEV & 310 & 0.000270 & 0.837462 & 0.42817198 & 1.89585610 \\
\hline SIZE & 310 & 25.619483 & 33.198812 & 28.79941881 & 1.687208024 \\
\hline $\mathrm{AQ}$ & 310 & 0 & 1 & 0.44 & 0.497 \\
\hline AGE & 310 & 6 & 83 & 34.23 & 12.187 \\
\hline COM & 310 & 2 & 22 & 4.5 & 2.559 \\
\hline DIR & 310 & 2 & 16 & 5.39 & 2.337 \\
\hline COA & 310 & 2 & 6 & 3.11 & 0.490 \\
\hline MAN & 310 & 0.000000 & 0.672477 & 0.04677989 & 0.99670259 \\
\hline
\end{tabular}

Sumber: Hasil Pengolahan Data SPSS IBM 19

Hasil uji t dapat dilihat dalam tabel 3 :

Tabel 3 Hasil Pengujian Hipotesis

\begin{tabular}{lcccl}
\hline Variabel & $\mathbf{B}$ & $\mathbf{t}$ & Sig. & Kesimpulan \\
\hline (Constant) & 0.074 & 0.714 & 0.476 & \\
ROA & 0.064 & 0.942 & 0.347 & Ha ditolak \\
LEV & -0.035 & -1.450 & 0.148 & $\mathrm{Ha}$ ditolak \\
SIZE & -0.002 & -0.610 & 0.542 & $\mathrm{Ha}$ ditolak \\
AQ & -0.014 & -1.264 & 0.207 & $\mathrm{Ha}$ ditolak \\
AGE & 0.000 & 0.500 & 0.618 & $\mathrm{Ha}$ ditolak \\
COM & -0.007 & -3.391 & 0.001 & $\mathrm{Ha}$ diterima \\
DIR & 0.002 & 0.947 & 0.344 & $\mathrm{Ha}$ ditolak \\
COA & 0.005 & 0.562 & 0.575 & $\mathrm{H}$ a $_{8}$ ditolak \\
MAN & 0.033 & 0.732 & 0.464 & $\mathrm{Ha}$ ditolak \\
\hline
\end{tabular}

Sumber: Hasil Pengolahan Data SPSS IBM 19 
Profitabilitas (ROA) memiliki nilai signifikansi sebesar 0.347 yang lebih besar daripada $\mathrm{a}=0.05$, maka $\mathrm{Ha}_{1}$ tidak diterima, artinya profitabilitas tidak memiliki pengaruh terhadap manajemen laba.. Besar-kecilnya nilai rasio ROA tidak mempengaruhi tindakan manajemen dalam melakukan manajemen laba karena terdapat alasan dan tujuan yang berbeda dalam melakukan manajemen laba.

Leverage (LEV) memiliki nilai signifikansi sebesar 0.148 yang lebih besar daripada $\mathrm{a}=0.05$, maka $\mathrm{Ha}_{2}$ tidak diterima, artinya leverage tidak memiliki pengaruh terhadap manajemen laba. Untuk keamanan perjanjian hutang perusahaan tidak harus bergantung pada manajemen laba.

Ukuran perusahaan (SIZE) memiliki nilai signifikansi sebesar 0.542 yang lebih besar daripada $\mathrm{a}=0.05$, maka $\mathrm{Ha}_{3}$ tidak diterima, artinya ukuran perusahaan tidak memiliki pengaruh terhadap manajemen laba. Dikarenakan perusahaan yang sudah besar belum tentu tidak melakukan manajemen laba.

Kualitas audit (AQ) memiliki nilai signifikansi sebesar 0.207 yang lebih besar daripada $\alpha=0.05$, maka $\mathrm{Ha}_{4}$ tidak diterima, artinya kualitas audit tidak memiliki pengaruh terhadap manajemen laba. Perusahaan yang diaudit oleh KAP big four belum tentu terbebas dari manajemen laba, itu semua tergantung dari kinerja dan independensi auditor.

Umur perusahaan (AGE) memiliki nilai signifikansi sebesar 0.618 yang lebih besar daripada $\mathrm{a}=0.05$, maka Ha $\mathrm{H}_{5}$ tidak diterima, artinya umur perusahaan tidak memiliki pengaruh terhadap manajemen laba. Perusahaan yang sudah lama berdiri belum tentu tidak akan melakukan manajemen laba.

Dewan Komisaris (COM) memiliki nilai signifikansi sebesar 0.001 yang lebih kecil daripada $\mathrm{a}=0.05$, maka $\mathrm{Ha}_{6}$ diterima, artinya komisaris independen memiliki pengaruh terhadap manajemen laba. Penambahan dewan komisaris akan mengurangi praktik manajemen laba di dalam perusahaan karena adanya pengawasan.
Dewan direksi (DIR) memiliki nilai signifikansi sebesar 0.344 yang lebih besar daripada $\mathrm{a}=0.05$, maka $\mathrm{Ha}_{7}$ tidak diterima, artinya dewan direksi tidak memiliki pengaruh terhadap manajemen laba. Ukuran dewan direksi tidak memiliki pengaruh pada optimalisasi dewan direksi dalam mendeteksi manajemen laba (Susanto, 2013).

Komite audit (COA) memiliki nilai signifikansi sebesar 0.575 yang lebih besar daripada $\mathrm{a}=0.05$ maka $\mathrm{Ha}_{8}$ tidak diterima, artinya komite audit tidak memiliki pengaruh terhadap manajemen laba. Pembentukan komite audit diduga hanya untuk memenuhi regulasi (Agustia, 2013). Kepemilikan managerial (MAN) memiliki nilai signifikansi sebesar 0.464 yang lebih besar daripada $\mathrm{a}=0.05$, maka Hag tidak diterima, artinya kepemilikan manajerial tidak memiliki pengaruh terhadap manajemen laba. Banyaknya kepemilikan manajerial tidak menjadi jaminan berkurangnya praktik manajemen laba.

\section{PENUTUP}

Berdasarkan hasil penelitian dapat disimpulkan bahwa Dewan Komisaris memiliki pengaruh terhadap manajemen laba, sedangkan profitabilitas, leverage, ukuran perusahaan, kualitas audit, umur perusahaan, komite audit, dewan direksi, dan kepemilikan manajerial tidak memiliki pengaruh terhadap manajemen laba. Penelitian ini memiliki keterbatasan yang dapat berpengaruh terhadap hasil penelitian, yaitu (1) Penelitian ini menggunakan periode penelitian yang relatif pendek, yaitu dari tahun 2013-2016; (2) Penelitian ini hanya menggunakan 9 variabel independen. Rekomendasi bagi penelitian selanjutnya yaitu (1) Menggunakan periode penelitian yang lebih panjang agar hasilnya lebih dapat digeneralisasikan; (2) Menambah variabel independen lainnya seperti kepemilikan institusional, kepemilikan asing, asymmetry information. 


\section{REFERENSI:}

Agustia, Dian. 2013. Pengaruh Faktor Good Corporate Governance, Free Cash Flow dan Leverage Terhadap Manajemen Laba. Jurnal Akuntansi dan Keuangan, Vol. 15 No. 1: 27 - 42.

Amertha, Indra Satya Prasavita, I Gusti Ketut Agung Ulupui dan I Gusti Ayu Made Asri Dwija Putri. 2014. Analysis of firm size, leverage, corporate governance on earnings management practices (Indonesian evidence). Journal of Economics, Business, and Accountancy Ventura, Vol. 17, No. 2: 259-268.

Aygun, Mehmet, Suleyman Ic, dan Mustafa Sayim. 2014. The Efeect of Corporate Ownership Structure and Board Size on Earning Management: Evidence from Turkey. International Journal of Business and Management, Vol. 9, No. 12: 123-132.

Bassiouny, Sara W. 2016. The Impact of Firm Characteristics on Earnings Management: an empirical study on the listed firms in Egypt. Journal of Business and Retail Management Research, Vol 10 Issue 3: 34 - 45.

Bassiouny, Sara W., Mohamed Moustafa Soliman, dan Aiman Ragab. 2016. The Impact of Firm Characteristics on Earning Management: an Empirical Study on The Listed Firms in Egypt. Journal of Business and Retail Management Research, Vol. 7, 2(2):91-101.

Degutis, Augustas dan Lina Novickyte. 2014. The Efficient Market Hypothesis: A Critical Review of Literature and Methodology, Vol 9, No. 2:7-23.

Jatiningrum, Citrawati, Mohamad Ali Abdul-Hamid, dan Oluwatoyin Muse Johnson Popoola. 2015. The Impact of Disclosure Quality on Corporate Governance and Earning Management: Evidence from Companies in Indonesia, Vol.6, S4: 118-125

Jensen, Michael C., 1986. Agency Cost of Free Cash Flow, Corporate Finance, and Takeovers. The American Economic Review, Vol. 76, No. 2:323-329.

Jensen, Michael C., and William H. Meckling. 1976. Theory of the Firm: Managerial Behavior, Agency Costs and Ownership Structure. Journal of Financial Economics, Vol. 3, No. 4: 305-360.

Komite Nasional Kebijakan Governance. 2006. Pedoman Umum Good Corporate Governance.

Kristiani, Kadek Emi, Ni Luh Gede Erni Sulindawati, dan Nyoman Trisna Herawati. 2014. Pengaruh Mekanisme Corporate Governance dan Ukuran Perusahaan Terhadap Manajemen Laba pada Perusahaan Manufaktur yang Terdaftar di BEI, Vol. 2, No. 1.

Lidiawati, Novi dan Nur Fadjrih Asyik. 2016. Pengaruh Kualitas Audit, Komite Audit, Kepemilikan Institusional, Ukuran Perusahaan terhadap Manajemen Laba. Jurnal Ilmu dan Riset Akuntansi, Vol. 5, No. 5: 1-19.

Monks, Robert A. G. dan Nell Minow. 2011. Corporate Governance. United Kingdom: John Wiley \& Sons.

Nugroho, Bernadus dan Umanto Eko. 2011. Board Characteristics and Earning Management. Journal of Administrative of Science \& Organization, Vol. 18, No. 1:1-10.

Scott, William R. 2015. Financial Accounting Theory Seventh Edition. United States of America: Pearson Canada Inc.

Siam, Yousef Abu, Nur Hidayah Binti Laili dan Khairil Faizal Khairi. 2015. The Relationship between Audit Committee Characteristics and Earnings Management among Jordanian Listed Companies: Proposing Conceptual Framework. Research Journal of Finance and Accounting, Vol 6 No. 18: 1-10.

Supriatna, Harrie. 2014. Pengaruh Kualitas Audit dan Faktor Lainnya Terhadap Manajemen Laba. Jurnal Bisnis dan Akuntansi, Vol. 16, No. 1a: 23-42.

Susanto, Yulius Kurnia. 2013. The Effect of Corporate Governance Mechanism on Earning Management Practice, Jurnal Bisnis dan Akuntansi, Vol. 15, No. 2: 157-167.

Sutrisno, Paulina. 2014. Return Saham Di Perusahaan Yang Terdaftar Di Bursa Efek Indonesia. Jurnal Bisnis dan Akuntansi, Vol. 16, No. 1a: 21-32.

Zen, Sri Daryanti, Merry Herman. 2007. Pengaruh Harga Saham, Umur Perusahaan, dan Rasio Profitabilitas Perusahaan Terhadap Tindakan Perataan Laba Yang Dilakukan Oleh Perusahaan Perbankan Yang Terdaftar Di Bursa Efek Jakarta. Jurnal Akuntansi dan Manajemen, Vol. 2, No. 2: 57-71. 